\title{
MEMORIES OF THE CHICAGO CONVENTION OF 1860
}

\section{Being interviezos with General Grenville M. Dodge of Council Bluffs and Judge Charles C. Nourse of Des Moines, the memoranda being obtained and put in form}

\author{
By F. I. Herriott
}

\section{Professor in Drake University}

The following interviews were obtained in the course of a search for data bearing upon assertions of two prominent historians relative to the actions of the representatives of the Republicans of Iowa at the Chicago Convention of 1860 which nominated Abraham Lincoln for the presidency, namely:

(1) The allegation of Professor A. B. Hart of Harvard University in his Life of Salmon P. Chase in "The American Statesmen" series, by means of a quotation to the effect that "some of the delegates from Iowa were 'on the trading tack' "so put in a context as to involve all of the delegation in the charge of sordid personal greed and venality. (See edition of 1899 , pp. 189-190, and repeated in the same terms in the "Standard Library Edition" of the series of 1917, pp. 189-190.)

(2) The assertion of Miss Ida M. Tarbell in her Life of Abraham Lincoln concerning the many and varied efforts of the opponents of Governor Seward's nomination to unite on Lincoln on the night before the convention was to decide, as follows:

While all this was going on, a committee of twelve men from Pennsylvania, New York, Ohio, Indiana, Illinois and Iowa were consulting in the upper story of the Tremont House. Before their session was over they had agreed that in case Lincoln's vote reached a specified number on the following day, the votes of the states represented in that meeting, so far as these twelve men could effect the result, should be given to him. Vol. I, p. 353.

The present writer has dealt with the gross injustice and the unmitigated impropriety of Professor Hart's aspersion upon the members of the delegation to the Chicago convention. ${ }^{1}$ His design to exhibit the actual part taken by Iowans in the pre-

\footnotetext{
"See "Iowa and the First Nomination of Abraham Lincoln" in the ANNaLs or Iowa for July, 1907, Vol. VIII, pp. 81-115, especially pp. 100-109.
} 
liminaries and proceedings of the National Republican Convention of 1860 and particularly the character and conduct of the members of the party sent to represent them has been partially accomplished. ${ }^{2}$

Both of the interviews contain recollections of more or less general interest outside of the immediate objectives of the interviewer that justify their preservation and publication-particularly the recollections and observations of Judge Nourse. The contents of the interview in each case were submitted subsequently to the one interviewed and his amendments or additions incorporated. The interview with Judge Nourse was, because of his defective vision, read twice to him in order to insure the accuracy of his original statements and additions or amendments.

The interview with General Grenville M. Dodge which follows took place in the Savery Hotel, Des Moines, on the evening of November 17, 1908. General Dodge was in Des Moines in attendance at a meeting of the Loyal Legion. The writer was indebted to the courtesy of Colonel G. W. Crossley of Webster City for the opportunity to meet him at the time when many counter interests attracted him. Previous correspondence with him had prepared the way, however, and the only adverse fact was the shortness of the time.

General Dodge frankly confessed to difficulty in recalling specific facts inquired about because, as he himself put it, he was "a youngster" and acted "as a messenger for Judd," and was completely absorbed "in helping him in his moves and maneuvers." Working "like a beaver," he hardly appreciated the significance of the crowding events about him or took particular note of the men who were, or who were reported to be, con-

2Ibid, and again in subsequent articles under the same title in the ANNıLs for October, 1907, Vol. VIII, pp. 186-220; for July, 1908, Ibid, pp. 444-466; for April, 1909, Vol. IX, pp, 45-64; and for Oetober, 1909, Ibid, pp, 186-228.

See also "Republican Presidential Preliminaries in Iowa-1859-1860" in ANNALs for January, 1910, Vol. IX, pp. 242-283; and "The Republican State Convention-Des Moines, January 18, $1860 "$ in ANNaLs for July-October, 1910, Vol. IX, pp. 401-446.

In another series dealing with the notable and decisive activities of the Germans in the anti-slavery propaganda affecting and determining the course of the Republicans of Iowa and of the northern Free states in the preliminaries of the National Republican Convention of 1860 the writer has displayed more or less of the antecedent developments controlling the Iowans at Chicago. See especially "The Germans of Davenport and the Chicago Convention of 1860" in Deutsch-Amerikanische Geschichisblaetter for July, 1910, Vol. X, pp. 156-163; also "The Germans of Iowa and the 'Two Year' Amendment of Massachusetts," Ibid, Jahrgang. 1913, Vol. XIII, pp. 202-308; also "The Germans of Iowa in the Gubernatorial Campaign of Iowa in 1859," Ibid, Jahrgang, 1914, Vol. XIV, pp. 451-623; and "The Premises and Significance of Abraham Lincoln's Letter to Theodore Canisius," Ibid, Jahrgang, 1915, Vol. XV, pp. 181-254. 
trolling or directing the course of events. Portions of the interview do not bear directly upon the convention at Chicago, but as one of the paragraphs deals with what was one of the notable perplexities of President Lincoln's policy in dealing with the liberated slaves during the early progress of the Civil War, and the other to a noteworthy decision of President Lincoln that was due in major part to the latter's visit to Council Bluffs and his chance meeting with the young surveyor of the projected railroad to the Pacific coast, both are included.

Grenville M. Dodge in May, 1860, was already a young man whom associates were beginning to watch with lively expectations of a notable career and they were not disappointed. At that time he was a civil engineer in charge of the initial surveys for the then much mooted railroad to the Pacific coast, and not long thereafter he became chief engineer of the Union Pacific Railroad Company. Upon the outbreak of the Civil War he offered his services to the government of President Lincoln, raised a company of infantry at Council Bluffs and entered the army with the rank of captain. His rise was rapid and his achievements under Generals Grant and Sherman were so brilliant and solid as to win for him the stars of a major general before the end of the Civil War. In 1866 he was elected by the Republican party to the Fortieth Congress. At the expiration of his term he declined renomination and thereafter devoted himself to his profession and to the furtherance of his investments and interests in railroad construction, mainly in the western and southwestern states. He became one of the influential leaders in financial circles in Wall Street in relation to railroads and their management. In 1898 President McKinley appointed him chairman of the Commission to Investigate the Conduct of the Military Department, particularly in care of the soldiers in camp and field during the war with Spain, concerning which there raged a violent and bitter controversy both in official and in popular circles. Many of the helpful reforms in the organization of our national military department that enabled the United States to cope so effectively and so promptly with the immense task suddenly put upon the government in the late war with Germany resulted from the findings and recommendations of General Dodge's commission. 
Somewhat of the energy and influence of Judge Nourse in 1860 may be inferred from the ensuing extract from a letter to the writer from Mr. A. C. Voris, President of the Citizens National Bank of Bedford, Indiana, under date of April 25, 1907, written in response to inquiries as to his recollections of the character of Iowa's delegates to the Chicago convention of 1860 and their participation in the caucus, or committee, referred to by Miss Tarbell. Mr. Voris was one of the delegates from Indiana. He says relative to the caucus in the small hours of Thursday morning:

As to the members of that Com [mittee] from Iowa. I regret I cannot say certainly. "I only remember that a Mr. Nourse of Des Moines, and of "Williamson and Nourse," seemed to be a ruling spirit in the convention, and though there were older men than he, it is likely he was one of that Com [mittee].

Mr. Nourse was only twenty-nine years of age at the time of the Chicago convention. He was known then as one of the "coming men" of Iowa and a factor to be reckoned with by all those concerned with the political affairs of the state. The next year he was elected by the Republicans to the office of attorney general of the state and served for four years of the Civil War. Later he was appointed judge of the Fifth Judicial District; but he soon resigned and thereafter steadfastly confined himself to the practice of the law.

As Judge Nourse recalled the exciting moments in the Chicago convention, following the third ballot that insured Abraham Lincoln's nomination, his memories of the scene in the great Wigwam became so stirring that his emotions aroused him from his chair, and almost blind though he was from cataract of the eyes, he leaped to his feet, threw out his arms in swinging gestures in reproduction of the wild gesticulation and vociferation of the Iowans joining in that pandemonium. In the rush of his recollections he dashed about the table in the center of the room in which we were in demonstration of his narrative. His abandon proved beyond cavil how intense and overwhelming must have been the excitement the instant the friends of the Commoner of Springfield realized the certainty of their triumph, if nearly a half century after memories of the scene could so arouse and carry away a cool collected lawyer of wide and varied 
experience in court and public forum. Judge Nourse's partial blindness enhanced the effect of his demonstration. It was a sight that the present writer will not soon forget.

I.

\section{NOTES OF A CONVERSATION WITH GENERAL GREN- VILLE M. DODGE, SAVERY HOUSE, DES MOINES, NOVEMBER 17,1908}

"My first interest in Abraham Lincoln came about as a result of my business interests and connection. For some time I had had business relations with Mr. N. P. Judd of Illinois. He was, as you know, Mr. Lincoln's manager in the campaign before the Chicago convention. He was an attorney for the Rock Island railroad, then in the course of construction across Iowa, and a large stockholder, and I believe an officer.

"Mr. Lincoln was also interested in the Rock Island railroad. $\mathrm{He}$ had acted as one of the leading attorneys in the celebrated litigation involving the right of the company to build the bridge across the Mississippi at Rock Island. In consequence of the acquaintance and association of Judd and Lincoln I had been asked to look after some of their land interests in Council Bluffs, which I had done for some time. These facts created and, of course, increased my interest in the promotion of Mr. Lincoln's public advancement.

"My going to Chicago and working for Lincoln's nomination was the result of a letter from Mr. Judd asking me to do so. I was an admirer of Lincoln and did not need much urging, but it was my relations with Judd that made me go and work like a beaver for Lincoln at that convention. I was only a youngster then of course. I was not very well acquainted with the older political leaders in the state. I knew Hoxie," Nourse and Kirkwood and some of the other delegates but none very intimately. I tried to exert what influence I had of course in bringing our delegation around to Lincoln but I was in a way a messenger for Judd,

${ }^{3}$ General Dodge was twenty-nine years old.

${ }^{4}$ Herbert Hoxie of Des Moines, later appointed by President Lincoln United States marshal for Iowa. After the war he became extensively interested in railroad construction. At the time of his death in 1886 he was virtually in charge of the Gould system of railroads in the Southwest. See Harper's Weekly, Dec. 4,1886, p. 784 . 
helping him in his moves and maneuvers. My business interests and my admiration of Lincoln combining, I was naturally very enthusiastic and earnest and hopeful of the final outcome.

"The caucus in the Tremont House the night before the nomination was made I recall but I cannot remember the names of the men who were there except Kirkwood. The others you mention (Gear, Dunham, Saunders) were doubtless present for they were influential and would naturally be called in for such a conference. As I recollect the conference was first called by some man from New York. The opposition to Seward wished to find out whether there was not enough second choice Lincoln men among the delegates from New England, Pennsylvania, New Jersey, Indiana and Iowa to secure the votes of those states for Lincoln after the first ballot. Judd's plan from the start was to unite the second choice men in the doubtful states on Lincoln. My memory is too vague now to recall names or faces of men from the other states; but I do recollect late or rather early the next morning after the conference had come to an agreement, going to Judd and talking with him about the agreement reached and the result if the agreement could be carried out. Judd was especially anxious to get our Iowa delegates to go solid for Lincoln after the first ballot. Our being neighbors was a fact that he urged very strongly. But our Seward men, while they wanted to nominate a strong man and were willing to go to him when it was evident that all would go to him, voted for Seward up to the last or third ballot.

"My memory of men and events back in those days is not so good as it was ten years ago; but when you prod it by calling my attention to some of the incidents I can recollect many of them. One fact I realize. In the hurry and confusion of ordinary times we do not always appreciate, or even discern the importance or significance of events taking place about us and in which we are more or less engaged. In $1860 \mathrm{I}$ felt of course much of the keen public interest in the discussion of political matters and yet as a young man I but vaguely sensed the vital import of the events that I was watching.

5John H. Gear of Burlington, afterward (1877-1881) Governor of Iowa and Mr. Clark Dunham, the editor of The Hawkeye of Burlington. Mr. Alvin Saunders, later mentioned by Judge Nourse. 
"I first met Mr. Lincoln at Council Bluffs in August, 1959. He had come up there by way of St. Joseph and the Missouri River to look after an interest in the Riddle tract, he had bought from Mr. Judd. I had returned with my party from a surveying trip and was camped in a ravine just north of the town, and had come down to the Pacific House to get a square meal.

"He heard of the arrival of the engineering party, and sought me out at the hotel. We sat down on a bench on the porch of the Pacific House and he proceeded to find out all about the country we had been through, and all about our railroad surveys, the character of the country, particularly its adaptability to settlement, its topographical features, in fact, he extracted from me the information I had gathered for my employers, and virtually shelled my woods must thoroughly.

"There are no accounts of his speech" that give any details as to what he said except perhaps in a very vague way. He dwelt largely upon the slavery question-the great subject in which we folks on the 'Missouri Slope' were then, as was the whole country, much interested. Mr. Lincoln set forth his views of the slavery question in connection with the settlement of the territory just across the Missouri River. The settlement of the new territories interested him very much and their commercial development was much in his mind. In the course of his speech he took occasion to commend the advanced stand taken by Kirkwood in his campaign for governor. I went with Kirkwood to some of the towns in the western part of the state, where he spoke. Kirkwood was regarded by a good many as pretty strong on the slavery question. It was natural that Lincoln should say a good word on his behalf.

"Before the speech I had no very definite ideas about Mr. Lincoln, but that speech in the square settled the matter. $\mathrm{He}$ convinced me and most of those who heard him that he knew what he was talking about and that he knew how to put the issues so as to bring out the strong points of the Republican position. He made many strong friends in our part of the state at that time.

'This was Lincoln's speech made on the public square in Council Bluffs the same day. 
"Mr. Lincoln staid with Messrs. Thomas Officer and W. H. M. Pusey while in the town-they had formerly lived in Springfield, Illinois.

"Years after it was the conversation at the Pacific House that led to the fixing of the eastern terminus of the Union Pacific at Council Bluffs. In 1863 I was stationed at Corinth, Miss., with my command. I had just previously marched up the Tennessee valley, which was a very rich district and full of rebel supplies. These I had destroyed. One of the results was that about three thousand negroes followed me back to Corinth and were on my hands. They were a great problem. They had to be fed and kept in order. My soldiers, or many of them, did not take very kindly to the idea of guarding, feeding and caring for 'niggers.' The ill feeling manifested itself in serious ways, the white guards shot darkies out foraging and tresspassing. What to do with them I hardly knew. Finally Chaplain Alexander of one of my regiments - a very able man-came to me and said that he could solve my negro problem. He asked to have 100 muskets assigned to him to arm a company of the darkies to guard the rest. He said that they would be able to do it with a little assistance. My ordnance officer refused to issue arms and ammunition to him and when Alexander came back to me and reported the situation I receipted for the arms and turned them over to him, not thinking much about the matter at the time for I was greatly relieved to have their care taken off my hands. The arming of those negroes produced a stir. Soon the Chicago papers had accounts of it. The discussion of what to do with the negroes was then becoming a live coal in political discussion. I soon realized that I had put my foot in it. But I concluded that silence was the better part of wisdom and said nothing. I knew that General Grant knew what I had done though I had made no report; and so long as he did not make trouble I felt fairly safe. One day General Grant transmitted an order from the War Department directing me to report at once at Washington. I thought my time was up and my head was going off, for I had done a very serious thing absolutely without orders.

"The event was not so fearful as I had reason to fear. President Lincoln had to decide upon the terminal of the Union Pacific and he had summoned me to give him the benefit of my 
first hand knowledge of the region and the probable developments. He recalled our conversation in Council Bluffs, and on the report I made to him he fixed the eastern terminus on the western boundary of Iowa in the townships that Council Bluffs is located in. About that time the government officers were begining to look favorably upon the notion of arming the negroes and I could offer some practical experience that was beneficial. I was thereupon given a general commission that enabled me to organize regiments directly and appoint the officers from my command which were duly commissioned at Washington. By this means I could reward my line officers and non-commissioned men. At first they did not look upon the offers or chances favorably but as the negroes proved that they could fight and under good training and discipline would make good soldiers, very soon my soldiers were anxious to secure commissions. The First Alabama Colored Regiment was thus organized by me and several other regiments."

\section{A DELEGATE'S MEMORIES OF THE CHICAGO CON- VENTION OF 1860}

\section{Ah Interview with Hon. Charles C. Nourse, Des Moines, APRIL 26 AND MAY 12, 1907}

"My memories of the Convention that met in Chicago, May 16-18, 1860, are not so definite as you probably wish. Nevertheless, events and men and measures that concerned us in those exciting days made a vigorous impression on my mind. I recall much in those days a great deal more clearly than I do happenings of ten years ago. However, I do not want to be held too strictly to account for details. You know in a few days now it will be just forty-eight years since we met in that Wigwam at the corner of Market and Lake streets.

"From the beginning of the serious discussion of candidacies in 1859, I was a Lincoln man. When I went to Chicago I felt strongly that two things had to be accomplished or all would be in vain in the forthcoming campaign. The first essential was to 


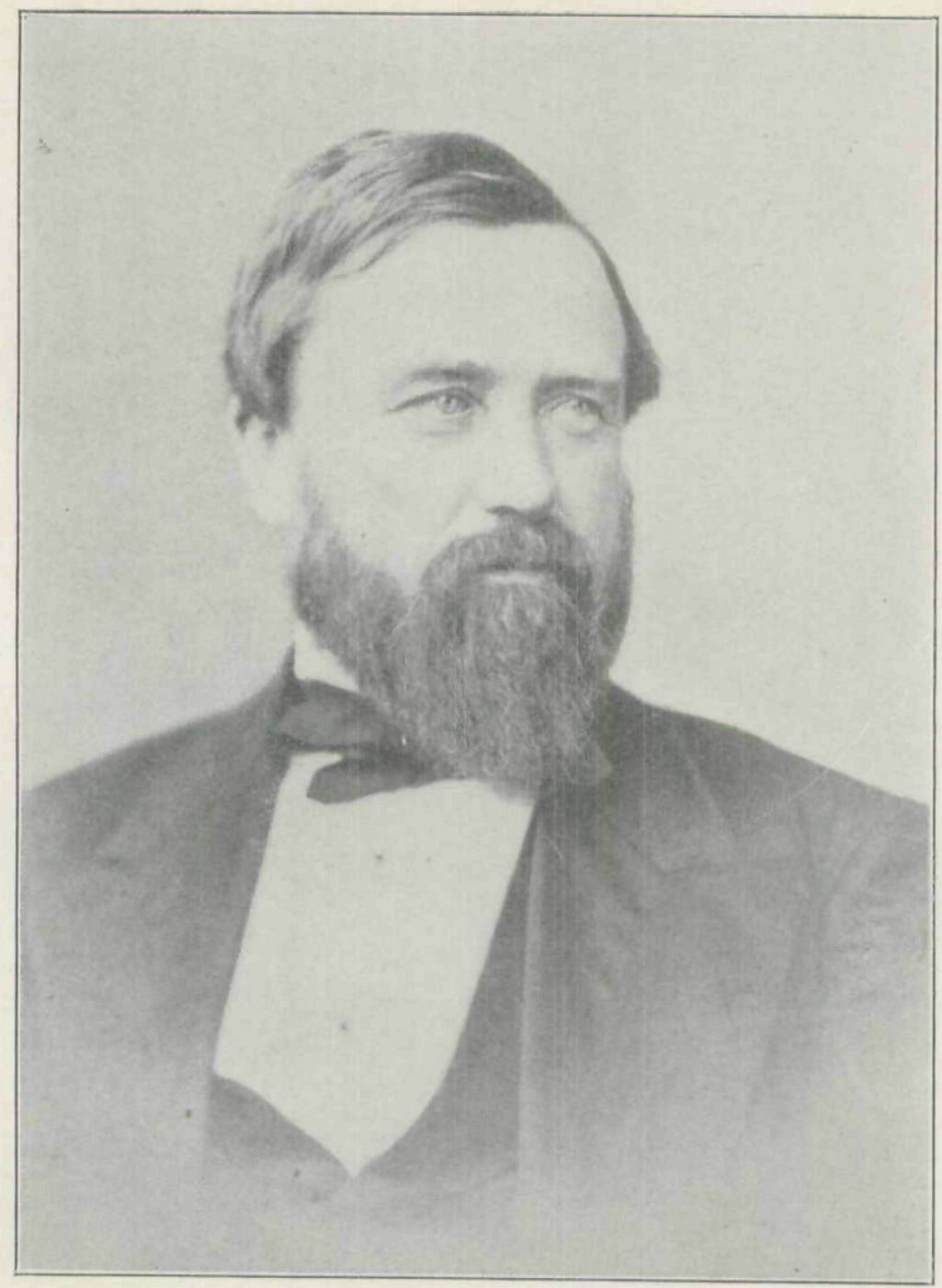

CHARLES CLINTON NOURSE

From a Photograph by W. Kurtz, Madison Square, New York, 1876 
prevent the nomination of William $\mathrm{H}$. Seward. The second thing was to nominate a man whose views on the slavery question were solid and clear-cut, who would represent and attract those in all the old parties who strongly opposed the extension of slavery and the aggressions of its leaders, and whose character and career would not suggest attacks upon the property rights of the southern slave owners. The selection of Lincoln I believed would meet the second condition of party success.

"My objections to Seward were based partly upon my opinion of the New York statesman and his character, and partly upon my knowledge of what the people here in Iowa, particularly in the southern tiers of counties, thought of him. To me, Governor Seward was a dangerous radical. He bud been intimately associated for over a decade with the extreme opponents of slavery, especially with the Free Soilers. He had used expressions in his speeches that seemed to us then to indicate that he was in favor of abolition or emancipation. Certainly this was the opinion of the great majority of the Democrats th ghout Iowa. At the same time he was associated with the old Cotton Whigs of New York to such a degree as to make him objectionable to those Whigs who opposed further compromises for the sake of holding the southern trade. The manufacturers and merchants of New York were anxious to curry favor with the southerners. They wished first and last to maintain the supremacy of the port of New York as the transshipping point or center of the cotton and ocean carrying trade for the Southern States. They wanted further to enjoy a monopoly in supplying the South with manufactured goods. Back of Seward stood vast commercial interests. Their leaders counseled against firmness in opposing the arrogant demands of Judah P. Benjamin and Jefferson Davis, and favored compromising and conciliatory measures. We had had enough of compromises that made the southerners more and more aggressive and domineering. Another fact adverse to Governor Seward, in southern Iowa particularly, was his hostile attitude towards the 'American' or Know Nothing party that had a very considerable representation in Iowa.

"These fears of Seward, or objections to his candidacy were not a dreamer's notions. They had been forced upon me as early as the Pierce-Scott campaign in 1852 and particularly in $\mathbf{1 8 5 6 .}$ 
In $1852 \mathrm{I}$ was elected county prosecutor of Van Buren County as a Whig. In $1854 \mathrm{I}$ was renominated. The Free Soilers were numerous enough in the northern part of the county to cause the convention to put a Free Soiler by the name of French on the ticket. For several reasons I was strong enough to win on my own strength, but my friends soon told me that I could not carry the Free Soiler along with me. You see a great number of the people in Davis and Van Buren counties had moved into that region when they supposed it was a part of Missouri. In the contest over the boundary the decision was largely in our favor. The fact that those southerners were in Iowa did not, however, reconstruct their notions or ways of thinking. A Free Soiler to them was an abolitionist, an equal suffragist who proposed to force on us negro equality both political and social. I worked manfully on behalf of French but I could not disabuse their minds and I was beaten. It was my defeat that induced my friends to make me clerk of the House of Representatives in 1854, as a sort of compensation or 'consolation prize.'

"In the Fremont campaign in $1856 \mathrm{I}$ canvassed nearly all the southern counties of the state for the State Central Committee, and I knew, or thought I knew thoroughly how strong the antiabolition and anticompromise sentiments were among the voters. By that time the old Whig party had disappeared as a national party organization. But we had large numbers of them in the state. Many, if not most of them were opposed to any interference with slavery in the Slave States, but they were just as much opposed to its extension. Many of them were strongly proslavery because they had come from Kentucky, Virginia and Maryland. We could not safely or sensibly antagonize them and Seward's speeches had made them very uneasy and suspicious. Finally, we had a large Know Nothing element in our region-just how large it was I cannot say now. But they made a tremendous noise and no one could really say whether the woods were full of them or not. The Bell-Everett vote showed that they were not a factor to be ignored. The most of them became Republicans and we believed that if not antagonized or offended nearly all of them would come to us. They made us lots of trouble in the southern sections. To all this element Seward was especially distasteful because as governor 
of New York he had pursued a course contrary to their views on Catholicism and the school question.

"Such objections were not captious or fanciful or mere makebelieve. If we were to unhorse the Democrats at Washington we needed every ounce of strength we could muster. It was suicide to take any serious risks. We had to have a candidate that would unite all factions and all sections of the Republicans and attract to us the other discordant elements that were, like we were, opposing the Democracy and draw to us the thousands of Democrats who were discontented and disgusted with the weakness of Buchanan's administration. The right man in my judgment was the man who had worsted Stephen A. Douglas in 1858.

"Abraham Lincoln had secured my admiration and firm support in 1858, because he had demonstrated his remarkable insight into the significance of the issues then disturbing us. His debates with Douglas had astonished us all by his profound thought and preeminent capacity for statesmanship. He was no artful dodger and he was no demagogue; he met the issues squarely and convinced the entire public that he knew and was master of the real problem. As soon as the lines began to be drawn and the date of the convention approached, I became convinced that Lincoln was the man we should nominate. Among the politicians, as the term goes, Seward had a large following. But Iowa could not be carried easily by anybody we might nominate. We had to fight, and to fight hard, to secure and to maintain control, and common prudence or 'good polities' if you please, as well as moral philosophy required that we nominate a man at Chicago who would carry our cause and the party through to victory.

"Seward probably had the largest popular following in Iowa at the time; and I think that such was the case in the convention that met in Des Moines in January, 1860. But we were practical politicians as well as ardent friends of the various candidates. We were chosen five months before the National Convention and none knew what might happen. Every practical political worker knows that winds and tides change suddenly and it would have been extremely foolish for us to be instructed then for anybody. We wanted to nominate a man that would win 
and we divided honorably and fought hard but it was not petty huckstering that controlled our conduct.

"The assertions of Professor Hart concerning our delegation has no justification. The fact that our Seward men held fast and fought from start to finish for their leader shows that a good portion of us were not wabblers or weak-kneed brethren. We original Lincoln men had to contend against tremendous odds-Seward's popularity and the money and hired workers of Thurlow Weed, the great manager of Seward's forces. We would call Weed a 'boss' nowadays. There were some, perhaps, in our delegation-but I recall none-as there were doubtless in every delegation, who considered the probabilities of personal advancement being an incidental result of the success of their own candidate-but it is unjust to Iowa's delegation to class us, as Professor Hart does, in his Life of Chase among corruptionists. Even if he means only office broking, cabinet appointments, or the like, he implies petty sordidness on our part; and honorable men do not rest easily under the implications of his statement.

"The correspondent of Chase on whom Professor Hart depends was without warrant, in my judgment, for his assertion respecting the delegates from Lee county. Dr. Walker and Senator Rankin were both men of great ability and solid character with a fine sense of honor regarding public matters. Neither pettiness nor desire for private gain were moving motives with either. Any one who knows the A B C's of politics knows that in the last struggle of the various factions and sections for the chief prizes of a convention that various sorts of combinations or 'trading,' if you please so to call it, result, but there is nothing essentially questionable about such proceedings. They are inevitable and, while now and then the result of petty trading and corrupt exchange, are not usually reprehensible.

"Colonel Voris, of Bedford, Indiana, gives me undeserved credit in saying that I was the leading spirit among the Lincoln men of the Iowa delegation. I was young and active and I worked like a Trojan and no doubt I helped somewhat. But the real leader of the Lincoln men was Colonel Alvin Saunders, of Mt. Pleasant. He was one of our big men in Iowa in those days, a forceful, clear-headed and efficient worker. He had managed the 
two campaigns of his fellow townsman, James Harlan, for the United States Senate, with rare discretion and marked success. He was widely acquainted in Indiana, Illinois, Kentucky and other states. He was, in fact, a whole team by himself. Another man who probably exercised as much influence as Saunders on behalf of Illinois's candidate was Governor Samuel J. Kirkwood. He was not a delegate, however. He had already won distinction by his course as governor. He was a great leader, a keen eyed statesman, and an adroit politician. He was extensively acquainted in Ohio where he had a state wide reputation before coming to Iowa. Saunders and Kirkwood probably did more than any others to bring the Iowa contingent around to Lincoln. ${ }^{7}$

"Miss Tarbell's statement I think is true, but I cannot say positively who represented Iowa in that committee of twelve to which she refers. Saunders and I slept in the same room at the Tremont Hotel where Illinois and Iowa had their headquarters. Early in the evening of the night before the nomination was to be made I had gone up to get some rest. I was fagged by the long strain of the day. The outlook for Lincoln was gloomy indeed; I recall Saunders coming in. $\mathrm{He}$ was depressed and dubious about our chances of overcoming the New Yorkers. Kirkwood came in later. He was nervous and very uneasy and glum. I remember a peculiar sound he made that was characteristic of him whenever he was worried over anything-a clucking or sucking sound as he fidgeted about. Both of them soon went out and I went to sleep. After midnight Saunders came in and in some excitement wakened me. He said that he, or Kirkwood, or both, had just come from a caucus or committee of various states and that all present had decided to throw their votes and influence for Lincoln after the first ballot. He was jubilant at the outlook. I cannot assert definitely, but I feel certain that he or Kirkwood or both had been in attendance at a meeting that

\footnotetext{
In a letter to me dated at Des Moines, August 29, 1906, Judge Nourse says: "We had originally, first, last, and all the time, eight men in the delegation earnestly in favor of Mr. Lincoln's nomination. The most active of them were James F. Wilson of Fairfield, Alvin Saunders of Mount Pleasant, Thomas Seeley of Guthrie [county], and myself; the others I am not sure of."

James F. Wilson later became a representative in Congress and a national senator from Iowa, becoming one of the prominent leaders of both bodies. Alvin Saunders was appointed the last governor of the territory of Nebraska; later he became a national senator from the state of Nebraska. Thomas Seeley had been a member of the Constitutional Convention in 1857 that drafted the present constitution of Iowa.
} 
practically decided Lincoln's fate. I mean by this, of course, that none of us before that agreement were certain that we could swing Pennsylvania and New Jersey into line and insure Seward's defeat, which we deemed necessary to party success in the fall.

“W. M. Stone's seconding Lincoln's nomination 'on behalf of two-thirds of the Iowa delegation was a case of undue excitement. The minutes are correct: $:^{5}$ he made the declaration, but he had no right to do so. All of us were astounded at his performance and laughed at his being carried off his feet. Stone was not an original Lincoln man. He was for McLean or Chase as I recall. His vote on the first ballot was cast for one or the other in accordance with the decision of the delegates before we went into the convention. But Stone was a man who was bound to distinguish himself some way or other. He supposed that his candidate would win of course, but when the deavening roar followed Judd's nomination of Abraham Lincoln-you know the Lincoln managers had packed the Wigwam while the Seward shouters were paradidng outside-Stone was carried off his feet. He thought he saw his chance and jumped up and proclaimed Iowa for Lincoln. The vote, however, showed that he was off; his own vote included.

"The summary, or poll of the delegation in the St. Charles City Intelligencer [May 24, 1860], is incorrect." There were

${ }^{5}$ The above refers to the following minute in the proceedings of the convention on Thursday morning after some fourteen different delegates had either nominated or seconded the nomination of different candidates, mostly either Seward or Lincoln: "Mr. Stone, of Iowa, Mr. President, I rise in the name of two-thirds of the delegation of Iowa to second the nomination of Abraham Lincoln. [Great Applause.]" See Chas. W. Johnson's Proceedings of the First Three Republican National Conventions, p. 149.

In its account of the Chicago Convention The St. Charles City Intelligencer of St. Charles City, in Floyd County, contained, May 24, 1860, the following:

"The Iowa delegation had their headquarters at the Tremont House, Before the opening of the convention they organized by appointing W. Penn Clarke chairman and took a ballot among themselves for the purpose of ascertaining how they stood in reference to the different presidential candidates. The result was as follows:

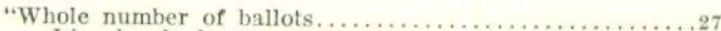

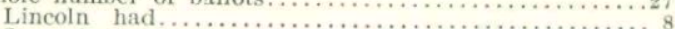

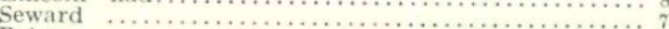

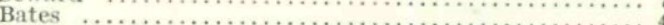

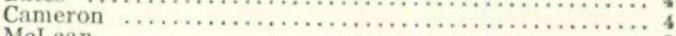

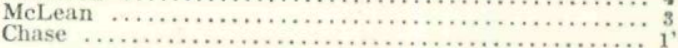

On the first ballot in the convention the delegation gave two votes to Seward, two votes to Lincoln, and one each to Bates, Cameron, Chase and McLean. The division of the delegates from Iowa was eight each for Seward and Lincoln and four each for the other candidates named. (See Johnson's Proceedings, p. 149.) Both the contemporary and the latter-day statements of the vote of the deleoration from Iowa have been curiously misrepresented or incorrectly reported. Professor Hart in his Life of Chase states that the Ohioan received no votes from Iowa. (see p. 190.) Iowans voted for Chase on all three ballots, William B. Allison of Dubuque and Judge William Smythe of Cedar Rapids being among the number. Judge Smythe "died in the ditch" with Chase. (For the ballots, see Johnson's
Proceedings, pp. 149, 152, 153.) 
nine Seward men on the delegation. I remember very distinctly the heated discussions we had when we refused to allow it to be counted. It took four delegates to make one vote and we would not announce less than one-half a vote. Mr. R. L. B. Clarke, of Mt. Pleasant, an ardent Seward man, was among us by proxy apparently because his name, you say, does not appear among the regular delegates. He insisted stoutly upon having his vote for Seward added and there was a hot debate when we refused. He got so angry that I flippantly said that if he did not look out he would make us think he had just escaped from the new lunatic asylum at Mt. Pleasant, that was just then a subject of hot political discussion.

"The Seward men were very confident of winning when we went into convention and they held fast to the end. Henry O'Connor of Muscatine, one of my successors as attorney general, in a ratification meeting afterwards at Muscatine, said there were two classes of men who voted for the New Yorker, 'plain' Seward and 'fool' Seward men, the latter voting for their candidate through thick and thin regardless of prospects and he, O'Connor, belonged to the latter class.

"We delegates from Iowa were a noisy and contentious set. We were all young and full of ginger and fight. We were divided so badly that our deliberations were not always the most dignified. The odd Seward vote not being counted put a wire edge on the tempers of the Seward men. In the convention we sat next to the New Jersey delegation. The contrast between us was marked. We were full of life and enthusiasm and perhaps not very considerate of each other's feelings or opinions. The Jerseyites were extremely dignified and proper in their conduct. From their solemn looking clothes and polite behavior, one to another, we would think they were all college professors or preachers. They seemed always to bow to each other in a most deferential manner whenever one spoke to another. When Lincoln was nominated we Lincoln men let loose such a series of war whoops and indulged in such fantastic antics that one of the Jersey delegates came up to me in one of my gyrations and very cautiously put his hand on my shoulder and said soberly, 'Why are you so excited? What is the need of so much feeling?' 'Why,' I said, letting forth another shout, 'we have nominated the best 
man in the country for president and beaten that New York crowd of wire pullers. Why shouldn't we shout? We came from Iowa where we were suckled by prairie wolves! Whoop!' and off again I went into a series of ear-splitting performances. I never was so happy in my life before or since.

"One of the comical results of the convention was the cost of the 'Iowa Headquarters' to the chairman of the delegation, William Penn Clarke. Clarke felt very much elated at his selection as chairman. I have forgotten whether we had concluded to choose him here in Des Moines or not. Any way, Clarke felt that he was certain of being so designated and he was aIso sure that it would promote his political ambitions which were robust at that time-he had been, you know, a strong candidate for the United States Senate against Grimes in 1858-and he wanted to make the most of his honor. So he went to Chicago several days ahead of time and rented a good sized room and had it labeled 'Iowa Headquarters.' We had no candidate to promote and no axes to grind and there was no particular need for so much show, but it gave us some prominence perhaps. The result to Clarke was hard on his pocketbook. There were a few on our delegation who liked wines and Kentucky Bourbon more than was good for them and at the convention such gay lords had plenty of encouragement to indulge their fondness for spirits. Clarke himself was not much given to such diversion, if at all. Those who were so addicted ordered such liquors as they desired and had the costs charged to the 'Iowa Headquarters.' The subjects under discussion at the conclaves of those partizans-the fates of candidates and the welfare of the nation were too important and pressing, you know, to permit those stern patriots to think of such prosy matters as immediate payment of the price. In the furious excitement just preceding and following the nomination they totally forgot that they had ordered or were ordering all sorts of high priced liquors. After the convention was over, and the delegates had dispersed, the bill was presented to Clarke. It took his breath, but he had to pay it and he realized as never before the beauties and benefits of fame among politicians.

"Another interesting reminiscence of Clarke's part in the convention comes to me. He had a slight impediment in his speech that became serious whenever he got excited. His office of 
chairman made him the spokesman of the delegation, who should announce Iowa's vote on the roll call. When our turn came on the first ballot Clarke arose. The excitement was intense. Iowa's vote, while known to be divided, was of consequence to the two leaders, Lincoln and Seward, and all were eager to hear our decision. Clarke opened his mouth to speak and couldn't say a word. There he stood painfully helpless in a vain stammer or stutter. We saw that he couldn't make it, and some one jumped up to relieve him and the situation by announcing the vote of Iowa for him.

"Among the influential considerations in making many of us fight Seward so hard at Chicago was the feeling that the forces of 'commercialism' and corrupt political rule would triumph by his election. The New York men 'talked big' about the need of money in the approaching election and the sources they would control and tap. It was notorious at that time that Weed manipulated the Albany legislature to secure New York City franchises for coteries or cliques of his personal and political friends. $\mathrm{He}$ was regarded as the most potent political manager in the country. The forces he controlled and worked through and with were what today we should unreservedly call the 'machine' elements. Such certainly was the horde of Seward shouters and workers led by the prize fighter Tom Hyer. One of the New Yorkers came up to me and said, 'It is absurd for you westerners to want to nominate an Illinois man or any other man than Seward. No man can carry Pennsylvania or Indiana unless he and his backers have plenty of the sinews of war.' I asked, 'What do you mean?' 'I mean money, of course,' he rejoined. 'Just so,' I retorted, 'and that is one of the reasons why we from Iowa and the West are afraid of you and are fighting you. You and your kind think you can purchase the election as you buy stocks. But you can't buy Iowa. We need a little money for ordinary campaign expenses but not to buy votes. With such methods as you fellows pursue at Albany endorsed at the polls and you will drain the national treasury dry. No, Sir! Mr. Seward must not be nominated. Not because we think he is personally bad or wants to do anything unrighteous, but because he could not control the forces that are back of him and that would work through him.' This fact of his bad company and his radical and reckless 
statements were the great causes of the general opposition to him.

"Seward's defeat was taken with very bad grace by many of his eastern champions. Some exhibitions are worth mentioning. A large number came west with us as far as Davenport to see the wonderful prairies of Illinois and the scenery of the Mississippi. At most of the stations where stops of ten minutes or so would be made some of the big guns from New York or elsewhere would be called out for a rear platform speech. Several of the New Yorkers referred deprecatingly to the nominee, apologizing for having a 'rail splitter' for the party's standard bearer-a man without the culture or experience and trained ability of the great statesman of Auburn, etc., and of similar strain. My blood boiled but I said nothing in the way of retort until we reached Davenport and then I concluded I couldn't hold in any longer. Some of those inconsiderate and ill advised gentlemen needed a little disciplining and I let them have it straight and hot. 'Why,' I exclaimed, 'such deprecation of the Commoner of Springfield and of the yeomen of the West! We of the West were born of women as were you of the East. We are sons of your fathers and of your bone and flesh. We have all the traditions that you have and more. We have been reared in the free fresh air of the prairies, redolent with sweet odors of wild flowers. We love liberty and will fight for our rights if need be. We have youth and vigor and are conquering a vast empire. Abraham Lincoln has shown himself to be a profound thinker. He is a powerful advocate of the cause our party represents. The convention has passed by the learned men and older leaders of the East and has chosen for its leader the great giant of Illinois. He is worthy of your respect and he will prove himself the greatest among all of us and you will yet concede it. ${ }^{, 10}$

"The tremendous applause that greeted my rejoinder indicated that I had struck a responsive chord."

\footnotetext{
${ }^{10}$ The episode referred to by Judge Nourse was probably an incident of the excursion of various eastern delegates to the convention to the Mississippi River, made as a result of the official invitations of the managements of the Chicago \& Galena and of the Chicago \& Rock Island railroad companies to participate in the excursion as their guests. (See Johnson's Proceedings, p. 167.) Among those who came to Iowa was no less an one than Mr. Thurlow Weed. His biographer informs us that efforts to get him to make a speech to the convention after the defeat of Governor Seward were unavailing because "Mr. Weed was already preparing to leave Chicago for the Prairies of Iowa." "Barnes' Life, Vol. II, p. 267.) Mr. Weed came to Iowa City where he stopped in connection with some private business matters, according to information given the writer by one of the citizens of Des Moines, who happened to be in that city at the time and met him at the hotel at which he staid.
} 


\section{CHARLES C. NOURSE TO SENATOR JAMES HARLAN}

In the way of striking confirmation of the general accuracy of Judge Nourse's recollections of the general considerations that coerced the judgments of the delegates of Iowa to the Chicago convention in 1860 there is reproduced a portion of a letter he wrote to Senator James Harlan, Iowa's senior senator at Washington, dated at Des Moines, June 6, 1860. Senator Harlan expected, and in general deemed expedient, and as a strong opponent of slavery desired the nomination of Governor Seward. Judge Nourse was a staunch supporter of Senator Harlan's and was writing him in explanation of his own course and that of others of the delegation at Chicago. The original letter is in the James Harlan manuscript in the possession of Mr. and Mrs. Robert T. Lincoln to whom the interviewer is indebted for permission to use.

Des Moines, Iowa, June 6, 1860

"The nomination of Lincoln gives us great strength in this Congressional District. I voted for Lincoln at Chicago on every ballot. By his nomination and the platform adopted we get rid of any issues in regard to the Fugitive Slave Law, Slavery in the District of Columbia, and 'No more Slave State' Doctrine. These questions about which republicans are not agreed, and about which there is not now and probably will not be any practical issue before the country, have been continually thrust into the canvass by Democratic stumpers. They were the whole staple of Dodge's tirade and with John Brown and Helper's Impending Crisis would have driven all old-line-Whigs and Fillmore men from us if Seward had been nominated. It is a fact that we cannot ignore that Clay, Fillmore and other Whigs did sustain the Fugitive Slave Law and did oppose any effort to disturb Slavery in the District and never gave any countenance to the unqualified doctrine of 'no more slave states.' With Seward's 
nomination we could not have held the same position as now. The question of Negro suffrage is another of the catch questions which would have been thrust into the campaign to our prejudice in case of Seward's nomination. We would also have lost much, if not all the capital we have in this campaign in the extravagance and corruption of the Administration, had Seward been our candidate. However honest and pure Seward may be, he is not a political economist and there is a general distrust in the Northwest of that class of N. Y. politicians into whose hands Seward, in case of his election, would in his magnanimity to his friends, have placed our P. O. and custom houses.

"These are the reasons, I think, which influenced the majority of our delegation to vote against Seward."

\section{CADETS OF TEMPERANCE}

We are much gratified to learn that a charter has been obtained by the youth of this place, for a Section of the juvenile branch of the great Temperance family, known as the Cadets of Temperance. The Cadets of Temperance embrace boys from twelve to eighteen years of age, and hold to the same sentiments and observances as the Sons. Every boy, whose parents or guardian will consent, should become a Cadet. Aside from the important fact that it will throw that most fearful of vices, intemperance, and elevate his nature and purify his heart by the noblest and most exalted moral teachings and influences, it will be a great advantage in an intellectual point of view. Each Section of Cadets elects a Minister of Affairs, from among the Sons, who assists in conducting affairs and preserving order. The Section will be organized next week, and is to be called, we learn, Hawkeye Section, No. 3, of Iowa.-Bloomington Iowa Democratic Enquirer, Jan. 27, 1849. (In the newspaper collection of the Historical Department of Iowa.) 
Copyright of Annals of Iowa is the property of State of Iowa, by \& through the State Historical Society of Iowa and its content may not be copied or emailed to multiple sites or posted to a listserv without the copyright holder's express written permission. However, users may print, download, or email articles for individual use. 